\section{Lavoisier's originality}

SIR,-Antoine Laurent Lavoisier is generally credited with the independent discovery of oxygen and its role in combustion and respiration. But the existence of his personal copy of the complete works of John Mayow suggests that his ideas were not as original as he claimed. Lavoisier's early detractors seem to have been justified even when they accused him of a lack of originality.

Mayow recognised the existence of oxygen, which he called Spiritus nitro aereo, in 1674 when he was experimenting in physiology at Oxford. $\mathrm{He}$ described the decrease in the "portion of air that made respiration possible and was essential to life as well as to the combustion of candles". He also described quite accurately the changes occurring in red blood cell pigment exposed to either "fresh" or "corrupted" air. He considered that the portion of air that made it "respirable" was fixed to this coloured compound in the blood cells and acted as an indicator of whether the blood was "respirable" (red, arterial blood) or "corrupted" (dark purplish, venous blood).

There are striking similarities between the writings of Lavoisier $^{2}$ and Mayow on this subject, although the formed insisted that he did not know the work of the latter ${ }^{3}$. Some eminent eighteenth and nineteenth century scholars, however, including Cuvier ${ }^{4}$, maintained htat he did, and Hoefer ${ }^{5}$ considered that Mayow was the "real father of modern chemistry and the inventor of the theory of respiration".

Lavoisier seems indeed to have known about Mayow's work because a letter $^{3}$ to him from Mr Koenig of Strasbourg, dated 1767, contained an invoice for 118 books, among them a copy of Mayow's De Sal Nitro. As Mayow's tract $\mathrm{De}$ Sal Nitro was only published in the Opera Omnia Medico-Physica one must conclude that this book was the Opera Omnia. The book I found recently in the library of the Academie des Sciences de Paris, with the inscription 'De la Bibliotheque de M Lavoisier, Registreur de Poudres et de Salpêtres de France, Inspector Générales du Roy', was one of the 1681 edition of Opera Omnia, published in The Hague. This book was in Lavoisier's personal library and then passed on to J. B. Dumas, who died in 1884. Dumas greatly admired Lavoisier and arranged for the publication of his works ${ }^{6}$. In
1937 the book was given to the Académie des Sciences.

Lavoisier, therefore, must have been familiar with Mayow's work when in 1777 he presented his memoires on oxygen and respiration ${ }^{2}$ to the Académie des Sciences, although in 1776 a letter from $M$ Magalhaes ${ }^{7}$ to Lavoisier suggests that Lavoisier was only then looking for Mayow's works. His subsequent protestation of ignorance $^{3}$ seems to have represented an eighteenth century version of scientific cheating.

\section{E. L. Gonzalez}

William Goodenough House.

London, WCI

1 Mayow, J., Opera Omnia Medico-physica Tractatibus Ouinque Comprehensa (Leers, the Hague, 1681). See Partington, J. R., A History of Chemistry, 2,

2 Lavoisier, A. L., Memoires sur la Respiration et la Transpiration des Animaux, 185 (Academie Royale des Sciences, Paris, 1777).

3 Oeuvres de Lavoisier, 7, Letter No. 59 (edit. by Fric, R.) (Editions Albin Michel, Paris, 1955).

4 Cuvier, G. L. C., Histoire des Sciences Naturelles (Masson, Paris, 1841-1845)

Hoefer, J. C. F., Histoire de la Chimie, 2, Tome II (Hachette, Paris, 1842)

- Oeuvres de Lavoisier, 1-6 (edit. by Grimaux, E.) (Imprimerie Imperiale, Paris, 1864 ).

7 Oeuvres de Lavoisier, 7, Letter No. 320 (edit. by Daumas M., and McKie, D.) (Editions Albin Michel, Paris, 1964).

\section{Amazon rain forests}

SIR,-The Amazonian rain forests are indeed "one of the world's great photosynthetic factories", as Thomas Jukes has recently stated (November 11, page 108 ), but he is wrong to add that they "maintain atmospheric oxygen". The total area of the Amazon basin rain forests is about $3 \times 10^{6} \mathrm{~km}^{2}$ and the above-ground biomass is on average about 25,000 tonnes $\mathrm{km}^{-2}$, but this huge mass of vegetation is not a net source of oxygen. Overall it is in equilibrium just as is any substantial area of climax vegetation.

Patches in the building and mature phases of the forest growth cycle do show net increase of fixed carbon and an accompanying release of oxygen, but this is balanced by decomposition of dying vegetation, in which oxygen is taken up, in patches of overmature forest and the following gap phase of the growth cycle. Man-made or natural catastrophes in which large areas are cleared and the vegetation destroyed by burning or natural processes of decomposition do locally and temporarily lead to fixation of oxygen, but these are followed by a vigorous regrowth of vegetation with a rapid build-up of biomass during which oxygen is released.
So the luxuriant regrowth which soon refills a jungle clearing is actually for a time a source of oxygen. What are altered by large scale clearance are the structure and species-composition of the forest, and unnaturally extensive clearance by modern man could progressively deplete the forest of its diversity and lead to reduction in numbers or even extinction of some plants or animals. There is also the possibility of altering reflectivity of the surface, hence the heat balance, hence, conceivably, local climate (Stewart P., Commonw. For. Rev., 55, 155-157; 1976). These are the dangers to be countered as "development" of the rain forest takes place.

T. C. WHITMORE

Commonwealth Institute,

Oxford University, UK

\section{Seveso: putting it right}

SIR, - With Alastair Hay's article on Seveso (October 14, page 538) is an item on alternatives to $2,4,5-\mathrm{T}$ in which it is stated that Amcide is made by Nissan in Japan.

Just to put the record straight, Nissan Chemicals manufactures ammonium sulphamate but Amcide is the trade mark of Albright and Wilson Ltd, which markets ammonium sulphamate in the UK.

\section{R. E. C. Hawkins}

Organics Sector,

Albright and Wilson,

Warley, UK

Alastair Hay adds: The article on alternatives to 2,4,5-T also mentions criticisms by environmentalists of the widespread use of polychlorinated biphenyls. In it the phrase "polychlorinated biphenyls (PCBs) such as DDT" should have read "polychlorinated biphenyls (PCBs) as well as DDT". Dichlorodiphenyltrichloroethane (DDT) is not, of course, a polychlorinated biphenyl.

The November 25 issue reported $\mathrm{Dr}$ Donald Lee as saying that $130 \mathrm{~kg}$ of dioxin (TCDD) was released in the accident at Seveso. Dr Lee has since indicated that his suggestion was that "given the worst possible situations up to $130 \mathrm{~kg}$ TCDD could have been produced". His figure does not refer to the quantity of TCDD discharged directly into the atmosphere; as far as he is aware no figures for the amount of TCDD remaining in and around the reaction vessel have been divulged. 